\title{
3 Nazi Sterilization Policy, Second-Order Injustice and the Struggle for Reparations
}

On 24 May 2007, the German Bundestag passed a declaration that ostracized the Nazi Law on the Prevention of Offspring with Hereditary Diseases of 14 July 1933. The declaration had been preceded by decades of struggle over an entitlement to reparations for those who had been forcibly sterilized under this law and over nullifying or ostracizing it. The terminological difference matters, as explained below.

The law, the MPs declared, was an "expression of the inhuman Nazi conception of 'life unworthy of living" (BT Drs. 16/3811 2006, 3) and the first step on the way to the "'euthanasia' mass murder program" (BT Drs. 16/3811 2006, 4). It had provided a legal basis for forced sterilizations and therefore constituted Nazi injustice. Seventy-two years after the end of the Nazi regime, it was the first time that a high-ranking German constitutional body declared the Nazi sterilization act itself, and not only the way it was applied, to be an injustice committed by the state. In 1988, the Bundestag had already proclaimed the rulings under this law to be Nazi injustice. The verdict then, however, did not apply to the law as such. This was now different:

The law itself is an expression of the Nazi ideology, which denies the inviolable dignity of every human being by subordinating the individual to the racist delusion of 'purifying the body of the people' [Volkskörper] and, as a final consequence, 'eradicating' it. Not only the violent measures based on this law, but also the 'Hereditary Health Act' as such, which legalized these violent measures, must therefore be regarded an expression of the inhuman Nazi notion of 'life unworthy of living'. (BT Drs. 16/3811 2006, 3)

The Bundestag, the declaration went on, "is doing so on the assumption that by ostracizing the 'Hereditary Health Act' as such, it has removed any doubts 
about its willingness to provide full satisfaction and rehabilitation to those affected" (BT Drs. 16/3811 2006, 4).

For the victims, the declaration finally provided the official moral rehabilitation they had been awaiting for so long: Now "they are no longer considered 'not worth of living", Margret Hamm, managing director of the Association of Victims of "Euthanasia" and Forced Sterilization (Bund der „Euthanasie“Geschädigten und Zwangssterilisierten, BEZ) told us in a personal communication. However, the declaration did not entail recognition of those affected as victims of Nazi persecution in the sense of the Federal Indemnification Act (Bundesentschädigungsgesetz, BEG); thus, the persons concerned still were not entitled to reparations under BEG until this point.

The faction of the Greens in Parliament (Bündnis 90/Die Grünen) had submitted an alternative motion proposing not to ostracize but to annul the Hereditary Health Act, thereby supporting the BEZ's central demand to declare the Act null and void (BT Drs. 16/1171). The majority in the Bundestag, however, rejected this motion, arguing that the Act could no longer be annulled as it had been automatically invalidated in 1949 for being incompatible with the Basic Law. Yet, Margret Hamm explained, historically this was not correct. The Act was never officially repealed. On the contrary, after 1945 and even after 1949, it remained in effect in various ways as German administrations, courts and governments continued to apply it. Courts and government bodies used the Hereditary Health Act well after 1949 as a reference for decisions on revision trials and reparation claims for persons who had been forcibly sterilized, thereby actively confirming its validity. We have called this practice, which reified the stigmatization of the victims, a second-order injustice (Braun and Herrmann 2015). In the following pages, we shall see that the 2007 declaration failed to address this second-order injustice.

This chapter reviews the politics of coming to terms with Nazi sterilization policy-or failing to do so-in the Federal Republic. More precisely, it examines the politics of reparations for victims of Nazi sterilization policy and reconstructs what was and was not subject to critical reflection in this process. I use the term 'politics of reparations' to refer to the politics of coming to terms with historic injustice in a broad sense, comprising acts of rehabilitation or redress, reparation schemes, public apologies and inquiries. This may lead to the adoption of reparation policies or the rejection thereof, take place in formal political arenas such as parliaments or courts or in the media and other public spaces, and involve state as well as civil society actors. I take a performatist approach to reparation policies here, understanding them as 
performative acts, as something that is being done-or not. From this perspective, the questions are: What is it that actors are actually doing when they are crafting reparation policies? What distinctions are made, what boundaries drawn, what value judgements implied, what responsibility assumed and what audience addressed? I draw on the approaches of Nicholas Tavuchis (1991) and Aaron Lazare (2004), both of whom worked with the concept of apology. According to their understandings, an apology is a performative act that involves certain things being done, or in fact requires they be done, in order to constitute a proper apology. These are: making a factual statement about what happened, issuing a moral verdict, determining that wrongdoing has taken place, accepting responsibility for it, and promising non-repetition. Insofar as rehabilitation and reparation policies are intended as acts of making amends for an historic injustice-and not merely compensation for damage caused by force majeure-they involve and require acts similar to those that constitute proper apologies. Taking a performatist approach also allows us to see that rehabilitation and reparation policies do not simply address matters of the past but constitutively connect the past, the present and the future: Actors engaging in reparation policies ${ }^{1}$ make factual statements about acts in the past; they convey a moral judgement about these acts and determine whether wrongdoing took place; they specify what was wrong about it; they accept responsibility in the present, thereby referring to normative principles or values that were violated; and they make a commitment to these norms and principles and promise non-repetition. Thus, establishing what should and should not qualify as a systemic injustice and which state actions in the past should or should not constitute an entitlement to reparations involves the confirmation of moral and legal standards for past, present and future. Therefore, struggles over reparations are struggles not only about the past but also about the present and the future as they inevitably imply the question of what kind of society we want to be: What wrongdoing has taken place? Was it so severe that it requires us to make amends? What normative principle has been violated and how important is it to us? Are we willing to commit to it? What kind of society are we now; in what way do we differ from the society that allowed these things to happen in the first place? What kind of society do we want to be in the future?

In this chapter, I interrogate the politics of coming to terms with Nazi selective sterilization policy. A note on terminology is in order: I deliberately 
avoid the terms 'eugenic' and 'eugenics' as well as the term 'euthanasia'. Although both acquired a more pejorative meaning after 1945, they were originally coined to denote something ostensibly positive: efforts to achieve a better-quality population (see Chapter 2 ) in the case of eugenics and the 'good death' in the case of euthanasia. Both terms are euphemistic and misleading. I refer instead to selective sterilization and selective sterilization policy. Selective sterilization means that certain persons or institutions claim the competence to select other persons for sterilization on the grounds that, for whatever reason, they consider these persons undesired in society. By selecting the undesired for sterilization, those who claim competence seek to reduce the number of the undesired by preventing them from having children. Note that selective sterilization does not necessarily rest on biologistic assumptions. Those who claim the authority to decide may also assume that undesired features may be passed down to future generations through procreation, education, or living conditions, as pointed out in Chapter 2.

To be sure, sterilization has not been the only practice to keep undesired people from having and raising children; institutionalization and sexual segregation, forced contraception, forced abortions, and forced removal of children are others. Sterilization policy was arguably the most widespread but by no means the only policy instrument for that purpose used by the Nazi regime. Selective sterilization, as I see it, can be understood as a biopolitical injury of normality. I use the concept of injuries of normality to denote human rights violations that refer to notions of normality in a threefold sense: First, they enact social norms and standards of health, fitness, productivity, or conformity, establish categories of differential social worth, and mark some people as socially inadequate, abnormal, deviant or deficient and ultimately being a burden or even a threat to society. Second, injuries of normality are by no means confined to situations of war, civil war or other situations of exceptional crisis. Rather, they occur also in states of normality-or what is considered by the unmarked to be normality. Lastly, injuries of normality are so ingrained and persistent because they are considered normal; as long as it goes without saying that mentally handicapped persons are a burden to society or that homosexual men endanger youth, it will be considered normal to reduce their numbers and deny them full civil rights status.

Forced sterilization is an injury in that it is both a violation of the person's physical integrity and a stigma imposed on her, a value judgement stipulating that she and persons like her are undesired and should preferably not exist at all. It is an injury of normality insofar as the value judgement refers 
to notions of normal vs. abnormal, deficient or deviant in relation to certain social norms and standards. It constitutes, furthermore, a biopolitical injury of normality that these norms and standards refer to notions of being a fit, healthy, functioning, productive and thus useful part of the social body. If this is accurate, then selective sterilization policies inevitably constitute biopolitical injuries of normality. Nazi sterilization policy was a particularly largescale, systematic and violent case of selective sterilization policy, manifesting and forcefully executing a type of biopolitical rationality. The question examined in this and the following two chapters is whether and to what extent this underlying biopolitical rationality was subject to critical reflection in West German reparation politics. I argue that the biopolitical rationality that drove Nazi sterilization policy did not vanish in 1945. Moreover, it not only did not vanish; it informed the politics of reparations for decades, manifesting in the persistent failure to acknowledge victims' claims to rehabilitation and reparation. In 2007, the Bundestag finally managed to condemn the biopolitical logic that had driven Nazi sterilization policy, but it failed to condemn or even reflect upon the enduring power of this logic in the Federal Republic.

In this chapter, I examine the politics of reparations for coercive sterilization under Nazi rule focusing on the question of what, if anything, was considered wrong about this policy. I suggest that we can read the relevant struggles as pertaining to the question of whether basic individual rights such as the right to physical integrity, the right to found a family, and the right to personal freedom apply universally, so that violating them on a systematic basis constitutes a severe historic injustice, or whether they apply only to persons who meet certain norms and standards. From this angle, we can see that for many decades systematic violations were not considered an undue infringement when directed against persons deemed mentally ill, mentally retarded, disabled or in some way abnormal or deficient. The $2007 \mathrm{dec}-$ laration condemned these violations under Nazi rule. However, it declared Nazi sterilization policy despicable not because it categorized people as being biopolitically inferior but because it served the despicable racist goals of the Nazi regime. It is thus unclear whether the Bundestag considers selective sterilization to constitute a biopolitical injustice in any case, regardless of the type of regime that performs it. 


\subsection{The Hereditary Health Act and its Biopolitical Rationality}

The Law for the Prevention of Offspring with Hereditary Diseases (Gesetz zur Verhütung erbkranken Nachwuchses, GzVeN) ${ }^{2}$, hereafter Hereditary Health Act, came into effect on 1 January 1934. It allowed for sterilizing a person if, according to the experience of medical science, there is a high probability that his offspring will suffer from serious physical or mental defects of a hereditary nature' (GzVeN \$1).

The Act explicitly mentions "1. congenital mental deficiency, 2. schizophrenia, 3. manic depression, 4. hereditary epilepsy, 5. hereditary St. Vitus' Dance (Huntington's chorea), 6. Hereditary blindness, 7. hereditary deafness, 8. serious hereditary physical deformity" (GzVeN \$1).

In addition to hereditary conditions, alcoholism served as an indication for sterilization. An amendment in 1935 also allowed for the termination of a pregnancy, formally with the woman's consent, if the woman was sentenced to sterilization but already pregnant at the time (GzVeN \$10a(1)). Further, the amendment allowed males to be castrated, formally with their consent, to "free them from a degenerate sexual drive" (GzVeN \$14(2)). This was primarily directed against homosexuals.

The decisions rested with the newly established Hereditary Health Courts (Erbgesundheitsgerichte), consisting of a district court judge, a state physician, and another physician trained in 'hereditary health' (Erbgesundheitslehre) (GzVeN \$6). Once a verdict was passed, the sterilization was required to be carried out, even against the will of the person concerned, meaning that the Act explicitly sanctioned the use of force. Notably, there was no mention of race in the law. Sinti and Roma were disproportionally affected as they were disproportionally categorized as 'feeble-minded' (Riechert 1995), but the Act did not explicitly target ethno-racial groups. In fact, condemning Nazi sterilization policy for being 'biologistic' or discriminating against members of certain racial groups is a misconstrual. Even hereditariness was not strictly a biological category. As Gisela Bock has shown, 95 percent of sterilization verdicts referred to indistinct psychiatric categories. 'Mental deficiency', schizophrenia, epilepsy and manic depression together accounted for nearly two thirds of indications (Bock 1986, 302f.). None of these categories was

2 Available online at http://www.documentarchiv.de/ns/erbk-nws.html. For an English version see http://ghdi.ghi-dc.org/sub_document.cfm?document_id=1521 (last accessed 10 April 2020). 
precise and well-defined, and the hereditariness of such conditions was difficult if not impossible to establish. However, this was of no consequence. Typically, sterilization candidates were identified by applying criteria of social behavior, conformity and functionality as indicated by school or work performance, sexual life, criminal record, receipt of welfare benefits, or records of institutionalization (Bock 1986, 306f.). The overall purpose of the policy was to improve the hereditary health (Erbgesundheit) and fitness (Erbtüchtigkeit) of the people, as Minister of the Interior Wilhelm Frick explained in 1940. Since Erbgesundheit was a "relative term", the identification of sterilization candidates was to take place by means of assessment of a person's performance (Leistungsfähigkeit), "taking into account the overall value to the community in terms of skills, talents, etc. as well as the existence of hereditary defects" (RMI quoted in Bock 1986, 236).

The Hereditary Health Act was certainly an instrument of biopolitical racism-not necessarily in the sense of systematically targeting Jews, Roma and Sinti, Poles or members of other racialized groups, but in the sense of pursuing the overall Nazi goal of racial improvement (Aufartung). Nonetheless, not all forced sterilizations were carried out on a legal basis. Several thousand Jews, Sinti, Roma, and Poles were sterilized in gruesome experiments in the camps on the basis of executive orders (Friedlander 1995); several hundred children of German women and Afro-French or African American soldiers who had been stationed in the Rhineland after World War I also suffered forced extra-legal sterilization (Pommerin 1979; Lauré al-Samarai and Lennox 2004). Between 1934 and 1945, approximately 360,000 people were legally sterilized under the Act (Bock 1986; Friedlander 1995); 5,000 to 6,000 women and 500 to 600 men died as a result (Bock 1986, 230ff.). The exact numbers, however, remain unknown.

Forced sterilization is a bodily violation, but it also imposes a stigma on a person, marking her as inferior and as a valueless member of the community. ${ }^{3}$ It is a verdict on her "overall value to the community", as Minister Frick termed it. Bearing this mark entailed a series of further discriminations: people lost their jobs, they were banned from marrying non-sterilized partners, they were banned from adopting children, and they lost many other opportunities in life. Whether or not the person concerned suffered from health repercussions due to the surgery, whether or not she wanted children-the 
stigma and the resultant discriminations constituted a violation of her personal integrity and right to human dignity. Thus, the injustice committed is not merely a question of the physical injury that may or may not be caused by the surgery; it is inherent in the act of selective sterilization as such. Ascribing differential worth to people according to their presumed performance, functionality and usefulness for the community and depriving those deemed deficient of their dignity and status as full members of the community-that is what Nazi sterilization policy did and what the Federal Republic failed to acknowledge over the decades that followed.

\subsection{No 'Forgotten Victims': Non-Reparation Policy after 1945}

After 1945, the Hereditary Health Courts were abolished; consequently, no new sterilization verdicts could be passed under the Hereditary Health Act. However, the Act was not uniformly repealed. The Allied Control Council did not include it in its list of legal acts that were permeated by Nazi ideology and therefore to be invalidated (Control Council Law No. 1 1945). Only in the Soviet occupational zone was it repealed (as a Nazi law by the Soviet military administration in 1946). In the British occupational zone, by contrast, the military administration decided to maintain it, not least to enable the persons concerned to have their cases reviewed in court (Tümmers 2009b). To do so, claimants were required to demonstrate that in their case the sterilization was unlawful because the Act had been improperly applied. They needed to convince the court that, for instance, the earlier verdict was based on a faulty diagnosis or on procedural errors. It was not uncommon for these trials to consult the same documents and reports that had been used by the Heredity Health Courts, and sometimes the same judges and experts were even involved (Tümmers 2009b). If the courts established that the sterilization had in fact been unlawful, the claimant could in principle apply for hardship compensation or, in some cases, seek to have the sterilization reversed (Hebenstreit 1983). The legal basis of these proceedings, however, was always the Nazi Hereditary Health Act. By implication, the just or unjust, rightful or wrongful nature of the Act as such remained unquestioned; only its former applications were at stake. Quite the reverse: the courts made the Act the reference for their rulings and thereby performatively confirmed its enduring validity.

This practice continued after the Federal Republic was founded in 1949. The Act was not repealed, and throughout the 1950 s and 60s, the courts con- 
tinued to use it as a reference in revision trials. Until the 1980s, no federal constitutional body ever declared the Act to be incompatible with the Basic Law. On the contrary, the Higher Regional Court (OLG) of the city of Hamm decided in 1954 that the Hereditary Health Act did not violate the rule of law or natural law and that those affected therefore had no right to compensation (OLG Hamm 1954).

In the same vein, jurist Ernst-Walther Hanack concluded in an expert opinion on the "Criminal Law Admission of Artificial Infertilization" of 1959 that the Nazi Hereditary Health Act did not contravene the Basic Law because the provision of compulsory sterilization served not the purpose of discrimination, disenfranchisement or humiliation, but rather the preservation of public health. In fact, repudiating compulsory sterilization would contravene the obligation to respect the rights of others (Harnack 1959, 87f.). Thus, he argued, the Hereditary Health Act could not be considered invalid according to Article 123 of the Basic Law because it did not conflict with the Basic Law. The Article proscribes that "[l]aw in force before the Bundestag first convenes shall remain in force insofar as it does not conflict with this Basic Law" (Art. 123(1) GG).

In the early years of the Federal Republic, this was by no means a minority view. Medical, legal and other experts, many of whom had been involved in racial hygiene and Nazi sterilization policy or even in the systematic killing of people with disabilities or certain disorders, openly debated the need for selective sterilization for reasons of public health or social welfare (Tümmers 2009a; 2011, 84ff., 162f.). The prevailing view among experts and policy makers was that selective sterilization was a rational, if not necessary, state practice, an appropriate policy instrument to achieve legitimate policy goals. Selective sterilization, in other words, was considered a normal instrument of modern statecraft. Thus, the Hereditary Health Act was predominantly perceived as a policy instrument for safeguarding the welfare of the German people, not as Nazi injustice. ${ }^{4}$ According to this logic, individual 'abuses' of the Act might have occurred, but the Act as such was not problematic. In this climate, the grievances of sterilization victims found no resonance in politics, in the courts, or in civil society. Reparation and rehabilitation for those affected were not on the political agenda. 
This did not change when the Federal Republic established a statutory entitlement to reparations for victims of Nazi persecution under the Federal Indemnification Act (BEG) of 1953. The entitlement was subject to restrictive territorial conditions; claimants were required to demonstrate that they had a spatial relationship to Germany within a certain time period (Brunner, Frei et al. 2009, 25). Among those who were in principle eligible on territorial terms, only those persons who were recognized as victims of Nazi persecution were granted the right to reparations. The BEG conclusively restricted this definition to those who had been persecuted for reasons of political opposition to the Nazi regime or for reasons of race, political opinion, religion or ideology (Weltanschauung) (BEG \$1(1)). Thus, entitlement to reparations was not determined on the basis of what a person had suffered, nor was it contingent on what one had done, on whether one had been a 'fighter against fascism', as was the case in the GDR (Goschler 2005, 361ff., Ludi 2006). Rather, entitlement to reparations was made contingent on whether a person belonged to one of the groups listed by the BEG. Yet not all groups that suffered persecution were listed. Why were some groups included and others not? From a performatist perspective, the question to be asked would be: What is it that the BEG does? The answer is: The BEG makes distinctions-distinctions according to the motives of the persecution that took place. It distinguishes between deserving and undeserving victims of Nazi persecution based on the motives of the perpetrators. It sets out a number of 'reasons' for targeting, tormenting, detaining, killing people that are so despicable that they constitute a reason for making amends. These reasons included those of race, political opinion, religion or Weltanschauung, but not those of sexual orientation, abledness, health status, productivity or functionality.

Those who had been forcibly sterilized were not included, nor were homosexuals, 'asocials', 'professional criminals', deserters, forced laborers, or those who were killed in psychiatric institutions (Evangelische Akademie Bad Boll 1987, Goschler 2003; Reimesch 2003; Goschler 2005; 2009). This exclusion, however, was by no means the result of thoughtlessness or forgetfulness. Therefore, the concept of the forgotten Nazi victims that arose in the early 1980 s is misleading. The discourse of forgotten victims addressed the persecution of those groups who were not included in reparation schemes and had not yet been included in discourses on Aufarbeitung und Wiedergutmachung, such as Roma and Sinti, forced laborers, homosexual men and sterilization victims. These men and women, however, had been not forgotten; they had, rather, been deliberately excluded from the reparation scheme. State Secre- 
tary Alfred Hartmann at the Ministry of Finance stated this unmistakably in 1957:

The Act for the Prevention of Offspring with Hereditary Diseases of 14 July 1933 is not a typical Nazi law, since similar laws also exist in democratically governed countries-e.g. Sweden, Denmark, Finland and in some states of the USA. The Federal Indemnification Act, however, grants compensation benefits only to persons persecuted by the Nazi regime and, in a few exceptional cases, to injured parties who have suffered damage as a result of particularly serious violations of constitutional principles. (BT PLP 1957, 10876 (A))

The message to the persons concerned was clear: You are inferior, and the state has the right to reduce the number of the inferior; thus, the state was right to do this to you and you have no right to accuse it of wrongdoing. Another argument to fend off reparation claims drew on the fact that the Nazi sterilization law was based upon a draft sterilization law produced by the Prussian State Health Council in 1932. This draft had been the result of longstanding efforts by leading eugenicists and racial hygienists in Germany to translate their ideas into policy programmes (Weingart, Kroll et al. 1996). The purpose of the Prussian draft had been to reduce the procreation of the hereditarily ill and 'inferior' (Bock 1986, 51f.); in that respect, it did not differ from the subsequent Nazi law. The only difference was that the Hereditary Health Act sanctioned the use of force (Bock 1986, 51).

The argument that selective sterilization was not a 'typical Nazi injustice' was thus not entirely wrong; indeed, the idea had not been invented by the Nazis. Likewise, it is true that selective sterilization laws existed in Sweden, Denmark, Finland and many US states. Today, we know that such laws existed in many more countries and, at some point, in most states of the USA (see Chapter 2). In more conceptual language, we can say that selective sterilization policies did not originate in Nazi ideology but in a biopolitical rationality that was deeply ingrained and operative in many modern states. By reasoning that selective sterilization was not a typical Nazi injustice and therefore should not constitute entitlement to reparations, policy-makers effectively classified selective sterilization as a normal instrument of modern statecraft. They thereby simultaneously normalized and confirmed the biopolitical rationality that had originally informed and motivated these human rights infringements and shielded them from problematization. In short, unlike the oppression of racial or religious minorities or of political opponents (with the 
exception of communists), the biopolitical motive of improving the fitness of the social body was normalized, rather than condemned, by excluding sterilization victims from reparation claims. The Federal Republic would not condemn persecution on biopolitical grounds as wrongdoing, let alone promise non-repetition.

On the whole, in the 1950 s and 60s, the view that selective sterilization programmes were a normal, useful, rational, science-based instrument of population policy prevailed. It was in this vein that the post-1945 debates about a possible new sterilization law continued (Tümmers 2011, 84ff.). One of the protagonists of these debates was hereditary pathologist Hans Nachtsheim. In the 1940s, Nachtsheim had been head of department for experimental hereditary pathology at the Kaiser Wilhelm Institute for Anthropology and performed, among other things, experiments on children with disabilities whom he obtained from the killing institution Brandenburg-Görden (Klee 2013, 427). He had also experimented with organs obtained from prisoners murdered in Auschwitz. After 1945, Nachtsheim continued to advocate "The Need for Active Hereditary Health Care", as he titled of one of his articles (Nachtsheim 1952; 1964).

In this mindset, courts and bureaucracies regularly refuted reparation claims on the grounds that selective sterilization was based on science rather than political violence. The justifications with which reparation claims were refuted thus resembled the justifications of Nazi sterilization policy. This is exemplified by the experience of Hans Lieser, whom we met in in 2010. Lieser told us that he had suffered coerced sterilization in 1942 and applied for reparation in the 1960s. In 1968, his application was dismissed by the district court of the city of Trier on the following grounds: ${ }^{5}$

It is evident from the attached files that the proceedings were opened and conducted against the plaintiff for the sole reason that, in the opinion of the Hereditary Health Court, the plaintiff suffered from hereditary deafness. Prior to its decision, the Hereditary Health Court obtained the expert opinion of the Director of the University Ear, Nose and Throat Clinic in Frankfurt/Main dated 4 February 1941, in which the expert concluded that the plaintiff was suffering from sporadic recessive deafness, which was a hereditary disease on 14 May 2010 in Kordel near Trier and obtained express permission from them to mention them both by name. 
in terms of the Law for the Prevention of Offspring with Hereditary Diseases of 14 July 1933. It is obvious that this scientifically based expert opinion alone led the Hereditary Health Court to order infertility treatment. Moreover, it follows from statutory regulation-hardship compensation pursuant to 1171 , subsection 4, no. 1, BEC-that, as a rule, when sterilization was carried out in the National Socialist state, a violent measure according to $\S 1$, BEC can only be assumed if the intervention was carried out without prior procedure under the Hereditary Health Act. (Rationale quoted in Hennig 1999, 13, emph. i.o.)

This was common procedure. The majority of such applications were rejected "because the sterilizations were carried out on the basis of a procedure under the Hereditary Health Act" (BT Drs. 10/6287 1986, 37). In other words, if the injury was based on proper procedure, it by definition constituted no act of violence. Hence, the justifications with which reparation claims were refuted resembled the justifications of Nazi sterilization policy.

In 1965, the Parliamentary Committee on Reparations (Wiedergutmachungsausschuss), established by the Bundestag in 1953, officially approved this practice by declaring that the Hereditary Health Act had not been a law of injustice (ein Unrechtsgesetz); accordingly, victims of coerced sterilization were not to be entitled to reparations. The Committee based its statement on an expert hearing that it had conducted in 1961 (BT 3 1961). Seven experts were invited to this hearing, among them Professors Hans Nachtsheim, Werner Villinger and Helmut Ehrhardt. Nachtsheim, as previously mentioned, had used children with disabilities for his research (Klee 2013, 427); Ehrhardt had provided expert reports for Hereditary Health Courts (Klee 2013, 127); and Villinger had served as a judge on Hereditary Health Courts and was also involved in the so-called $\mathrm{T} 4$ programme, that is, the institutional killing programme, as a provider of medical reports (Klee 2013, 641). At the hearing, Nachtsheim maintained that the Hereditary Health Act was not to be conflated with Nazi racial policy because it was "an apolitical law intended to protect the hereditary health of the German people" (BT 3 1961, 33). Ehrhardt likewise underlined that the law "in its core content is indeed in line with the scientific convictions of the time, as well as those of today" (BT 3 1961, 25). Not all invited experts, however, were of this opinion. Ministerialrat Dr $\mathrm{Karl}^{6}$, an administrative physician, argued that the very purpose of the Act, 
"namely to achieve a 'people's body (Volkskörper) purified of biologically inferior hereditary material"', was immoral and that the sterilizations ordered under it constituted "a bodily injury emanating from a law of injustice". The state, he concluded, had the duty to compensate this injury by means of a special reparation law (BT 3 1961, 48). The Reparations Committee, however, agreed with Nachtsheim, Ehrhardt and Villinger and denied entitlement to reparations for victims of Nazi sterilization. As late as 2008, the Federal Ministry of Finance affirmed this conclusion and the method by which it was obtained, stating in a letter to the Petitions Committee of the Bundestag that all aspects of reparation law had been "carefully examined by the Reparations Committee after hearing leading experts in psychiatry" (BT Drs. 17/8729 2012, 7).

It was not until 1969 that essential parts of the Hereditary Health Act were repealed. The remaining portions were repealed in the course of the 5 th Criminal Law Reform in 1974, not, however, for reasons of incompatibility with the Basic Law. It was not until 1986 that a German court, the Kiel District Court, found that the Heredity Health Act had been incompatible with the Basic Law (Scheulen 2005, 5). The Federal Constitutional Court, however, was never concerned with the issue and consequently never stated an incompatibility between the Hereditary Health Act and the Basic Law.

\subsection{The 1980s: The Struggle Gains Momentum}

In the 1980s, the situation changed. A new phase of coming to terms with Nazi crimes began with a surge of research and commemorative activities. In this context, crimes against the so-called 'forgotten victims' met with new public interest, among them Nazi medical crimes.

One important event was the famous 1985 speech by then-President of State Richard von Weizsäcker on the fortieth anniversary of the end of the war, in which he not only called May $8^{\text {th }}, 1945$ the day of liberation but also commemorated several groups of 'forgotten victims', among them the victims of forced sterilization and institutional killings. Moreover, a number of civil society initiatives began to address the "forgotten victims" exclusion from reparations and demanded a revision of the reparation scheme (Die Grünen im Bundestag \& Fraktion der Alternativen Liste Berlin 1986; Deutscher Bundestag 1987; Tümmers 2011, 272ff.). In 1986, Gisela Bock's ground-breaking book on coerced sterilization under Nazi rule was published (Bock 1986), and 
civil society groups formed that began to research individual psychiatric institutions' involvement with the systematic killing of patients and persons with disabilities.

The Association of Victims of "Euthanasia" and Forced Sterilization (BEZ) played an important role in articulating these activities, as did the movement for the reform of psychiatry and the Study Group for Research into Nazi "Euthanasia" and Forced Sterilization (Arbeitskreis zur Erforschung der nationalsozialistischen "Euthanasie" und Zwangssterilisation). Among them, the BEZ was the only organization founded by and for citizens affected by coerced sterilization or institutional killing. Founded in 1987, it acted as a self-help group, an interest group, and an initiative for commemoration and civic education (Braun 2017). Its main objectives were to achieve full moral and legal rehabilitation, to have the Hereditary Health Act annulled by the German Bundestag, to achieve recognition as victims of the Nazi regime, and to receive reparations under the Federal Indemnification Act (Bundesentschädigungsgesetz, BEG). The overarching goal of these demands, however, was to overcome the stigma imposed on those affected and to ensure that nothing of the sort would ever take place again. In particular, the formal annulment of the Hereditary Health Act was of great importance to the BEZ, asthey assumed that the act of annulment (Nichtigkeitserklärung) would necessarily be followed by sterilization victims' recognition as Nazi victims and consequently by their entitlement to reparations under the BEG. For the BEZ, nothing short of reparation entitlements under the BEG would rescind the status of 'second-class' victims allotted to them. Only annulment of the Act and provision of full rights to reparations could reverse the stigma. However, the efforts of the BEZ failed. To this day, the victims of Nazi sterilization policy are entitled to no reparations under the BEG.

\subsection{Reparations as the Greater Injustice?}

We can thus speak of an enduring politics of denial and non-recognition that has never fully been reversed. It was bolstered by the core assumption that selective sterilization policies as such were a relatively normal, rational and science-based instrument of modern statecraft, even if the Nazi state might have used it improperly. Hence, Nazi sterilization policy was in principle considered rational and lawful. In the 1980s, a new argument emerged to refute reparation claims, referring this time not to science and the law but to nothing 
less than justice. If one were to grant entitlement to reparations to persons who were forcibly sterilized, as the argument went, one would in fact exacerbate existing injustices. Remarkably, this argument was first put forth by the abovementioned Prof. Ehrhardt at the public hearing on "Making Amends and Reparations for Nazi Injustice" organized by the Parliamentary Committee for the Interior in 1987 (Deutscher Bundestag 1987). The hearing marked a milestone in West German politics of coming to terms with the Nazi past insofar as it placed the so-called forgotten victims centre stage. For the first time, in addition to academic and policy experts, persons who were personally affected were invited as expert participants. Chairperson Klara Nowak and member Fritz Niemand attended and gave testimony on behalf of the BEZ. One of the academic experts invited was Prof. Helmut Ehrhardt, who argued:

The last point of view concerns the actual victims of the Nazi regime. What will they say if, for example, an anti-social drunkard who was wrongly sterilized because of hereditary factors is now to be put on the same level as all those who, as respectable citizens, were tortured in a concentration camp for years simply because of their race, their faith or their political convictions? A compensation scheme for those sterilized would in many cases amount to a disavowal and a mockery of the genuine idea of reparation. (Deutscher Bundestag 1987, 288)

One year later, the Federal Ministry of Finance confirmed this view in a letter of reply to the BEZ, writing:

[...] the expert hearing conducted by the Cerman Bundestag in 1987 made it clear that revising the comprehensive laws on reparations and compensation for war-induced losses would not lead to greater justice but, on the contrary, to injustice in the relationship among the aggrieved parties.?

In the years that followed, the BEZ received a number of letters from the federal government reasoning, similarly, that improved compensation for sterilization victims or surviving victims of 'euthanasia' would be tantamount to an injustice to other Nazi victims (Braun 2017). For instance, in 1990, the Parliamentary Secretary of State at the Federal Ministry for Education and Research, Manfred Carstensen, wrote: 
Additional improvements are not possible if the principle of equal treatment is to be respected. They would lead to injustice towards the many severely affected Nazi victims who have received or are still receiving statutory benefits under the Federal Indemnification Act. $^{8}$

Another letter from the Federal Chancellery, dated 2 February 1996, reiterates the position of the Ministry of Finance almost verbatim. Revising the law on reparations and compensation for war-induced losses, the letter says, "[...] would not lead to greater justice but, on the contrary, to injustice in the relations between the aggrieved parties." 9

Nevertheless, the struggle for reparations made some, albeit slow, progress in the 1980s. In December 1980, the German government established a Hardship Fund for Victims of Coerced Sterilization under the General Act Regulating Compensation for War-Induced Losses of 1957. These victims could then claim one-time compensation of 5,000 DM; as of 1988, they could also apply for additional monthly payments under certain conditions ${ }^{10}$. Hardship compensation under the Fund, however, did not imply a recognition of wrongdoing. The purpose of the Fund was to compensate for damage suffered due to the war, not due to an injustice. In accordance with this purpose, claimants first needed to prove that they had in fact suffered significant harm to their health as a result of sterilization surgery. The health damage requirement was lifted in 1990. Until 2002, benefits were granted only if claimants were in a situation of acute social distress. Although several initiatives were launched in the 1980s and early 1990s for a new, more inclusive reparation scheme (Braun 2017), none of them found a majority in the Bundestag. According to the federal government, in February 2012, a total of 13,816 persons who had been forcibly sterilized had received onetime hardship compensation, and a total of 9,604 were receiving additional monthly benefits (BT Drs. 17/8729 2012, 3f.). June 1990, LAV NRW OWL, D107/73.

9 Federal Chancellery, letter to the BEZ of 2 February 1996, LAV NRW OWL, D107/73.

10 The monthly payments amounted to $100 \mathrm{DM}$ at first, from 1 January 2004 they were raised to $100 €$, from 1 January 2006 to $120 €$, from 1 January 2011 to $291 €$ (BT Drs. 17/8729 $2012,3)$. 


\subsection{Ostracization or Annulment}

The members of the BEZ and those who supported them struggled not only for reparations but also for moral and legal rehabilitation. The hardship compensation as such included neither an acknowledgement of wrongdoing nor a condemnation. Key to the struggle for rehabilitation became the question of annulment.

In 1986 and 1987, the faction of the Greens introduced a motion in the Bundestag proposing that the Hereditary Health Act be annulled (BT Drs. 10/4750 1986; BT Drs. 11/143 1987). The Bundestag, it was posited, should declare that the Act had been a Nazi law of injustice in that it categorized certain individuals as inferior and socially undesirable. It was necessary to condemn the Act because its very purpose, namely raising the hereditary quality of the German people, was reprehensible. The Bundestag should therefore annul the Act and all verdicts made under it.

The majority of the parliamentarians disagreed with this argument. In 1988, they adopted a declaration that condemned the rulings of the Hereditary Health Courts but not the Act as such (BT PLP 11/77). It took another ten years to pass the NS Annulment Act of 1998 (NS-AufG), which effectively cancelled the rulings. The main argument against annulling the Act was that it had never been part of German law after 1949; it was incompatible with the fundamental provisions of the Basic Law and had for this reason automatically gone out of force when the Basic Law was established. Thus, it could logically not be annulled, as argued for instance by then-Minister of Justice Klaus Kinkel (FDP) in 1987 (Kinkel 1987; Incesu and Saathoff 1988).

This, however, was merely the personal opinion of Minister Kinkel. In fact, as we have seen, the Hereditary Health Act was not ruled unconstitutional by a competent constitutional body until the 1980s. On the contrary, it was actively applied and thus constantly confirmed by the courts.

In the 1990s, the debate on annulling the Hereditary Health Act diminished. It was not revived until 2005, when a new initiative was launched, mainly by former Minister of Justice and long-standing supporter of the 
BEZ Hans-Jochen Vogel (SPD) ${ }^{11}$ and the National Ethics Council (NER). ${ }^{12}$ The Ethics Council called on the Bundestag to extend its former condemnation of the sterilization verdicts to the Hereditary Health Act itself (Newsletter Behindertenpolitik 2006,5$)$. This initiative prompted the two proposals mentioned at the outset of this chapter: the proposal by Bündnis 90/The Greens to annul the Act (BT Drs. 16/1171 2006) and the proposal by the factions of the governing parties, CDU/CSU and SPD, to ostracize it (BT Drs. 16/3811 2006). ${ }^{13}$

It was the firm hope of the BEZ that having the Act annulled would provide full moral and legal rehabilitation to the victims and consequently constitute an entitlement to reparations under the BEG (Incesu and Saathoff 1988). However, the BEZ also wanted to draw attention to the injustices constituted by the fact that the Hereditary Health Act had been continuously applied after 1949. The annulment proposal by B9o/The Greens at least mentioned this fact. The Bundestag, however, rejected the quest for an annulment on the grounds that

[th]e Act had already ceased to be in force when the Basic Law entered into force to the extent that it violated the Basic Law, pursuant to Article 123(1) Basic Law. [...] The law thus no longer existed and can no longer be repealed. (BT Drs. 16/5450 2007, 1)

Unfortunately, this was not correct. The Act was not repealed when the Basic Law entered into force; rather, the courts continually referred to it in the course of review trials. No high-ranking court or constitutional body ever established its incompatibility with the Basic Law. The Bundestag refused the opportunity to confront this fact. It thus failed to address the countless bureaucratic and governmental acts, court rulings, and expert opinions in the 1950 s and 1960s that not only confirmed the Hereditary Health Act by applying it but often expressly vindicated it. The Bundestag failed to see that the question of unconstitutionality had not been ignored but had rather been answered in the negative. By accepting the argument that the Act had ceased to

11 Hans-Jochen Vogel was a member of the National Ethics Council at the time and in this position motivated the Council to issue a statement on the matter, as he told us in a personal communication. Earlier, in 2004, the BEZ had turned to the Ethics Council to request support in their struggle to annul the Hereditary Health Act. An abridged version of the NER statement is printed in the Newsletter Behindertenpolitik (2006).

13 The Left supported the call for annulment in a Question (Kleine Anfrage) submitted to the government on the matter (BT Drs. 16/2307, 2006). 
exist in 1949, the majority denied the second-order injustice that had continued to take place until well after 1949 and failed to face the necessity for the Federal Republic to acknowledge not only its predecessor's wrongdoing but its own. In turn, they also failed to address the continuity of biopolitical reasoning underlying these performative confirmations and open justifications.

\subsection{Comprehensive Rehabilitation?}

The 2007 declaration by the Bundestag clearly condemned the Nazi sterilization law. The declaration meets all the requirements for an official apology: It names the wrong that has taken place, it names the major perpetrators, namely physicians and heads of institutions, and it names the victims, recognizes their suffering and expresses sorrow and respect. Moreover, in substance if not in wording, it confronts the biopolitical rationality that motivated these crimes, namely the delusional idea of 'purifying the body of the people' (Volkskörper). The Bundestag thereby distanced itself clearly and beyond doubt from the Nazi sterilization policy. It did not, however, condemn selective sterilization as such, and it did not confront the second-order injustices that occurred in the Federal Republic or the enduring biopolitical rationality that informed and motivated them. It treated Nazi sterilization policy as an isolated case of exceptional evil, clearly delineated in space and time, obviating the need to confront origins, overlaps, parallels or continuities that would go beyond these spatial and temporal demarcations. This is expressed quite clearly in the rationale for the declaration:

Although eugenic ideas and eugenic sterilization laws were already widespread internationally before 1933, the Law for the Prevention of Offspring with Hereditary Diseases of 14 July 1933 (Hereditary Health Act) marks a historical caesura. This caesura is characterized by the fact that the allegedly 'hereditarily ill' persons were degraded to mere subjects of state disposal by this law. (BT Drs. 16/3811 2006, 1)

It does not suffice to condemn only the applications of the Act, so the rationale continues, given that the applications cannot be separated from the Act. The reasoning as to why this cannot be done, however, deserves closer inspection:

A distinction between law and application requires a functioning separation of powers. This prerequisite was not met in the totalitarian Nazi state. [...] 
Against the background of a totalitarian state practice, the legal orders and the forced sterilizations carried out on the basis of these orders cannot be separated from each other. (BT Drs. 16/3811 2006,3)

Hence, only under the conditions of a totalitarian state was the Act itself determined to deserve condemnation and not only its application. Would a policy of selectively sterilizing the undesired, the 'useless', the unproductive be less despicable if pursued by a non-totalitarian state? Would it be acceptable to violate someone's bodily integrity, personal freedom, right to have and raise children if that person were declared inferior? In the context of the Nazi state, the declaration argues, the Hereditary Health Act was "the first step on the way to the 'euthanasia' mass murder program" (BT Drs. 16/3811 2006, 3). It can certainly be argued that this is correct insofar as we now know of significant personal, practical and ideological continuities between the Nazi sterilization policy and the institutional killings (Friedlander 1995). Yet it is unclear what the argument actually expresses: that selective sterilization necessarily entails mass murder-which would be historically incorrect-or that forced sterilization is unproblematic when it does not do so.

It is the merit of the Bundestag to have condemned Nazi sterilization policy for its-biopolitical-purpose of 'purifying the people's body' and to have stated that the purpose as such contravenes respect for human dignity. Yet it remains unclear whether, in the view of the Bundestag, the practice of selective sterilization is to be condemned, whether it is wrong for any political regime to assign a differential moral status to people according to their fitness, productivity and usefulness to the community, to make their rights to respect and state protection contingent on this status. By confining the issue at stake to the Nazi era, the Bundestag does several things at the same time: It acknowledges severe wrongdoing on the part of the predecessor regime and names perpetrators, victims, the wrong that occurred, the suffering it caused, and the reason why it was wrong. However, it evaded the question of whether the wrong-selective sterilization-is inherently wrong or only wrong under certain circumstances. In a certain sense, it thereby avoids making a promise of non-repetition insofar as it does not condemn the use of selective sterilization under conditions of a constitutional democracy. It further avoids addressing the second-order injustices that took place after 1945 and exonerates the Federal Republic from confronting its own wrongdoing. In short, the Bundestag failed to distance the Federal Republic explicitly and unambiguously from the biopolitical rationality that motivated selective sterilization policy in the past, 
to state that this biopolitical rationality is incompatible with who we are as a state and a society in the present, and to make a commitment to non-repetition in the future.

In hindsight, this was most probably the last word in the struggle for reparations for forced sterilization. After 2007, the debate was discontinued; given that very few of those concerned are still alive, it is unlikely to be reopened. What remains open, however, is the question of whether biopolitical rationality is considered compatible or incompatible with the kind of society we want to be. 